\title{
Developing and Evaluating a Camp-style Leadership Enhancement Program for Nursing Students
}

\author{
Oh, Seung $\operatorname{Eun}^{1 \oplus} \cdot \operatorname{Lim}$, Ji Young $^{2 \oplus}$ \\ ${ }^{1}$ Seoul Women's College of Nursing \\ ${ }^{2}$ Department of Nursing, Inha University
}

Purpose: The aim of this study was to develop a camp-style leadership enhancement program (CLEP) and evaluate its effects to provide basic data for developing such programs for nursing students. Methods: The study design was a randomized control pre/post-test. There were 35 participants each in the experimental and control groups for a total of 70 participants. The content and structure of the CLEP reflected 13 core concepts extracted using a systematic literature review. The program included a two-day camp-style program with eight modules consisting of lectures, individual and team activities, group discussions, team presentations, and feedback from the lecturer. The impacts of CLEP were measured using self, transformational, and servant leadership. Results: Pre-homogeneity between the group participants' general and leadership characteristics was confirmed. After the CLEP, the experimental group showed a significant increase in self, transformational, and servant leadership. Conclusion: These findings suggest that universities utilize the performance-based self-learning CLEP to increase leadership among nursing students.

Key Words: Leadership; Nurses; Universities; Students; Education

\section{INTRODUCTION}

The healthcare market is characterized by competition, including advancements in medical technology, increasing demands of medical consumers, and strengthening evaluation metrics. As nurses comprise up to $30 \sim 40 \%$ of all hospital personnel, the management of nursing human resources is vital to hospital management [1]. It is critical for nurses to demonstrate leadership in a changing healthcare environment.

Leadership has been emphasized as a key competency for nurses. The University of Colorado Hospital used leadership as an evaluation criterion for nurses' promotion [2], and the Carolinas Medical Center reported that advancing leadership over six months led to positive effects in the formation of peer relationships [3]. In Korea, nurse leadership is also key for comprehensive nursing management activities [4]. Specifically, more leadership among nurses leads to greater job satisfaction, organizational commitment and lower burnout rates [5]. Similarly, nurses with higher leadership levels had better nursing service levels. Nurses with self-leadership traits positively impacted organizational engagement as well as their job performance [6].

To develop nurses with leadership that matches environmental changes occurring in medical institutions, promoting leadership in nursing colleges and building relevant educational programs are critical. The US Institute of Medicine asserted that leadership education for nursing students is the responsibility of nursing educators [7]. Lee and Kim [8] emphasized leadership and communication skills as mandatory, basic abilities of nursing students. Leadership skills are among the evaluation standards in nursing education curricula, and some hospitals prefer to hire nurses with leadership skills [9].

In undergraduate nursing programs in Korea, leadership is only covered as a minor subject, and leadership skill education is insufficient. The Korea Accreditation Board of Nursing (KABON) [10] emphasized leadership as one of the learning outcomes of the undergraduate curriculum and called for diverse education measures to improve the

Corresponding author: Lim, Ji Young

Department of Nursing, Inha University, 100 Inha-ro, Michuhol-gu, Incheon 22212, Korea.

Tel: +82-32-860-8210, Fax: +82-32-874-5880, E-mail: lim20712@inha.ac.kr

- This article is a condensed form of the first author's doctoral dissertation from Inha University.

Received: Nov 6, 2018 | Revised: Dec 8, 2018 | Accepted: Dec 18, 2018

This is an open access article distributed under the terms of the Creative Commons Attribution Non-Commercial License (http://creativecommons.org/licenses/ by-nc/3.0), which permits unrestricted non-commercial use, distribution, and reproduction in any medium, provided the original work is properly cited. 
leadership of nursing students. Nevertheless, it is impossible for nursing students to participate in regular curriculum leadership programs provided by university at the headquarters, as the actual course of nursing is mostly block-based curriculum because of clinical practice. Therefore, it is necessary to develop a none-curriculum type leadership program to reflect the characteristics of the nursing department's curriculum.

Analyzing previous research on leadership for nursing college students, self-leadership, transformational leadership, and servant leadership were reported in a number of studies. Min et al. [11] showed that self-leadership is an important factor for nursing students, and self-leadership is a factor that not only helps individual growth but also helps college students enter a society where self-leadership is needed. Futhermore, when self-leadership is increased, it is accompanied by autonomy and passion and it makes continuously practice to achieve that goal. Sung [12] reported on the improvement of transformational leadership as one of the developmental tasks that must be achieved because the college student era is a time to find his or her identity, design the future, and lay the foundation of a mature adult. Servant leadership is suitable for organizations where various experts, such as medical institutions, work together as a team because it promotes mutual trust and impact between members [13]. Therefore, it is suggested that nursing students' leadership enhancement programs should be composed of programs that can improve various types of leadership.

Other degree programs have already included leadership development programs in their undergraduate courses, including a customized, technology-based leadership camp program for engineering students [14], a leader-nurturing program for humanities students [15], and a 21st-century leadership model for female university students [16]. The leadership education programs delivered at universities in Korea can be divided into four components: (1) classroom-link, (2) student-participation, (3) education training, and (4) international exchanges. Among these types, education training using camp programs is being provided in many schools [17].

Nevertheless, most existing leadership studies on nursing students have generally focused on exploring the relationship between leadership and related variables or on identifying factors that influence leadership itself. Consequently, developing and implementing a camp-style leadership program focused on undergraduate nursing students is necessary. In this study, we developed a camp-style leadership program that operates based on the voluntary participation of students with the aim of improving leader- ship of nursing learning goals presented by KABON [10].

\section{Purpose}

The aim of this study was to develop and evaluate a camp-style leadership enhancement program (CLEP) for nursing students with the goal to establish such a program in the future.

\section{Hypotheses}

The hypotheses of this study were as follows: The experimental group, which participated in the CLEP, would have higher self-leadership (Hypothesis 1), transformational leadership (Hypothesis 2), and servant leadership (Hypothesis 3) compared to the control group, which did not participate in the CLEP.

\section{METHODS}

\section{Study Design}

This study involved a randomized control group, pre/ posttest design to identify the effects of the CLEP on nursing students' leadership.

\section{Participants and Sample Size}

Participants were students at a nursing university selected based on the following criteria: 1) did not attend prior nursing management lectures, 2) no prior experience in a leadership enhancement program, and 3) understood the study purpose and agreed to participate.

The G*Power program, Version 3.1.9.2, was utilized to determine the required sample size using the following criteria: an effect size of .8 , a power of .8 , and a significance level of .05 [18]. The required sample size comprised 52 individuals: 26 in the experimental group and 26 in the control group. Considering a 30\% dropout rate, 70 individuals (35 in each group) were recruited and randomly assigned to the groups using a random number table.

\section{Measurement}

\section{1) Self-leadership}

For this study the Self-Leadership Questionnaire developed by Prussia, Anderson, and Manz [19] and modified by Lee [20] was employed. The tool comprised 23 items: 9 behavioral and 14 cognitive strategies. Each item was rat- 
ed on a 5-point Likert scale, with higher scores indicating a higher level of self-leadership. The Cronbach's $\alpha$ in Lee [20] was .87; in this study it was .92.

\section{2) Transformational leadership}

The Multifactor Leadership Questionnaire created by Avolio, Bass, and Zhu [21] and modified by Sung [12] was used. The tool comprised 12 items: two for charisma, three for inspirational motivation, three for intellectual stimulation, and four for individual consideration. Each item was rated on a 5-point Likert scale, with higher scores signifying a higher level of transformational leadership. The Cronbach's $\alpha$ in Sung [12] was .930; in this study it was 87 .

\section{3) Servant leadership.}

For this study the servant leadership tool formulated by Spears [22] and modified by Jun [23] was utilized. The tool comprised 10 items. Each item was rated on a 5-point Likert scale, with higher scores denoting a higher level of servant leadership. The Cronbach's $\alpha$ in Jun [23] was .93, and in this study, it was .86.

\section{Development of the CLEP}

A systematic literature review and structure formation were used to create the CLEP (Figure 1).

\section{1) Systematic literature review}

The literature review was performed using the system- atic review guidelines from the Preferred Reporting Items for Systematic Review and Meta-Analyses [24]. The end goal was to analyze the contents of leadership programs utilized in existing literature to provide basic data to develop the CLEP. Selection criteria were as follows: conducted with university students, implemented a leadership enhancement program, and reported appropriate statistics and results. Exclusion criteria were as follows: animal experiments, pre-clinical tests, and studies published in other languages (except Korean or English). The search period constituted 10 years: August 2005 to August 2015.

International studies were searched using MEDLINE and Embase; Korean studies were searched using KoreaMed, the National Library of Korea, the National Assembly Library of Korea, and the Research Information Sharing Service. Searching terms according to PICO were as follows. P (patient) was "university student" or "college student." I (intervention) was "leadership" or "leadership program." C (control) had no limitation. O (outcome) was "transformational leadership," "self-leadership," or "servant leadership." After excluding duplicates, 306 international and three Korean studies were identified. Next, these were assessed based on the inclusion and exclusion criteria, which resulted in 23 studies. Finally, 10 studies were chosen by evaluating research quality using the methodology checklist developed by the Scottish Intercollegiate Guidelines Network [25]. For these 10 studies, the specific content of the leadership program, module construction, period, and operational methods were analyzed (Table 1 ).
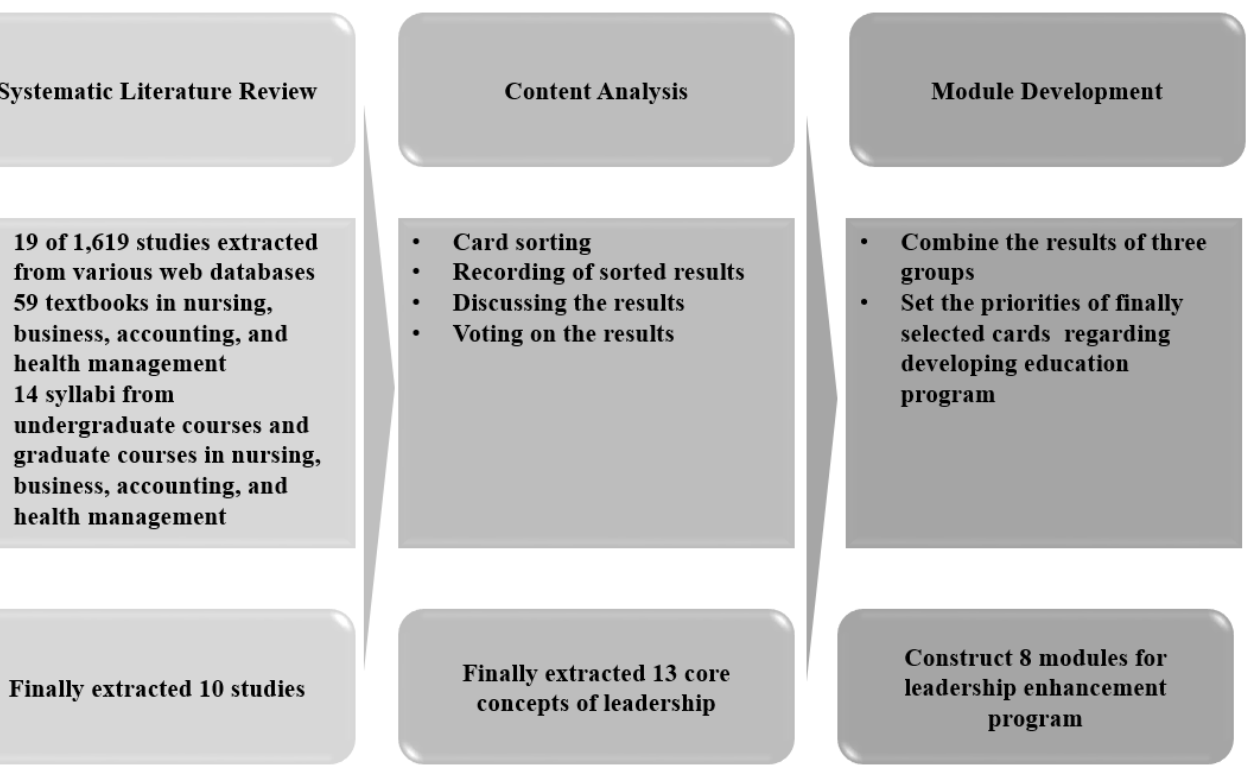

Figure 1. Developing process of the camp-style leadership enhancement program (CLEP). 
Table 1. Mapping of 13 Core Concepts and 64 Extracted Concepts from 10 Studies

\begin{tabular}{|c|c|c|}
\hline Core concept & Index of study* & Extracted concepts from 10 studies \\
\hline $\begin{array}{l}\text { Understanding } \\
\text { leadership }\end{array}$ & $1,2,3,4,5,10$ & $\begin{array}{l}\text { 1. Introduction to leadership } \\
\text { 2. Understanding of self-leadership } \\
\text { 3. Understanding of leadership } \\
\text { 4. 1) Leadership competency and effect, 2) Authoritarian leadership model } \\
\text { 5. Leadership theory; 10. Leadership development }\end{array}$ \\
\hline $\begin{array}{l}\text { Self-understanding and } \\
\text { exploration }\end{array}$ & $1,2,3,5,8$ & $\begin{array}{l}\text { 1. Self-understanding } \\
\text { 2. Rule of making belief } \\
\text { 3. 1) Self-understanding, 2) Self-exploring } \\
\text { 5. Self-understanding } \\
\text { 8. Self-understanding }\end{array}$ \\
\hline Increasing self-esteem & 1,9 & $\begin{array}{l}\text { 1. Increasing self-esteem } \\
\text { 9. Self-esteem }\end{array}$ \\
\hline $\begin{array}{l}\text { Establishing a vision and } \\
\text { setting goals }\end{array}$ & $1,2,3,8$ & $\begin{array}{l}\text { 1. Establishing vision and goal } \\
\text { 2. Designing vision } \\
\text { 3. Establishing vision } \\
\text { 8. Think big and leave trace }\end{array}$ \\
\hline Leadership development & $1,2,3,4,5,8,9$ & $\begin{array}{l}\text { 1. 1) Leadership core competencies, 2) Leadership development } \\
\text { 2. 1) Making positive energy, 2) Assistant role } \\
\text { 3. Teamwork training } \\
\text { 4. 1) Role and needs of mentor and mentee, 2) Respect, 3) Care } \\
\text { 5. Thinking of win-win } \\
\text { 8. 1) Emotional intelligence development, 2) Team building } \\
\text { 9. Plan of leadership development }\end{array}$ \\
\hline $\begin{array}{l}\text { Negotiation and } \\
\text { resolving conflicts }\end{array}$ & $2,3,5,8$ & $\begin{array}{l}\text { 2. 1) Overcome threatening, 2) Method of saying no } \\
\text { 3. Conflict management } \\
\text { 5. Endless makeover } \\
\text { 8. Negotiation }\end{array}$ \\
\hline Overcoming stress & 2 & 2. Overcome stress \\
\hline Communication & $3,6,8,10$ & $\begin{array}{l}\text { 3. 1) Effective communication, 2) Conversion of stereotypes } \\
\text { 6. Communication } \\
\text { 8. Communication } \\
\text { 10. Goal of communication }\end{array}$ \\
\hline Time management & $3,5,8$ & $\begin{array}{l}\text { 3. Time management } \\
\text { 5. Starting with thinking of end } \\
\text { 8. Plan and execution }\end{array}$ \\
\hline Setting priorities & 5 & 5. Prioritize the ones you care about first \\
\hline Self-management & $3,4,5,6,9,10$ & $\begin{array}{l}\text { 3. Self-management } \\
\text { 4. Consistency of behaviors } \\
\text { 5. Leading self-life } \\
\text { 6. 1) Self-management, 2) Importance of self-leading } \\
\text { 9. Satisfaction and perfection } \\
\text { 10. Self-directed learning }\end{array}$ \\
\hline Problem-solving & $7,9,10$ & $\begin{array}{l}\text { 7. Problem-solving } \\
\text { 9. Resource utilization } \\
\text { 10. 1) Maintenance and evaluation, 2) Feedback }\end{array}$ \\
\hline Human relationship & $2,4,5,8$ & $\begin{array}{l}\text { 2. Human relationship } \\
\text { 4. Affirmation of social relations } \\
\text { 5. 1) Creating Synergy, 2) Understanding others } \\
\text { 8. Cultural understanding }\end{array}$ \\
\hline
\end{tabular}

*1=Kim et al. (2015), 2=Min et al. (2010), 3=Park (2011), 4=Daniel et al. (2014a), 5=Daniel et al. (2014b), 6=Craig et al. (2008), 7=Kristofer et al. (2007), 8=Brandon et al. (2013), 9=Angelique Skoulas et al. (2012), 10=Deborah et al. (2011) 


\section{2) Structure formation}

Step 2 involved analyzing the formation of the structure and contents required to develop the CLEP. Based on the literature review results, 13 core concepts of leadership programs were extracted: (1) understanding leadership, (2) self-understanding and exploration, (3) increasing self-esteem, (4) establishing a vision and setting goals, (5) leadership development, (6) negotiation and resolving conflicts, (7) overcoming stress, (8) communication, (9) time management, (10) setting priorities, (11) self-management, (12) problem-solving, and (13) human relationship. These 13 core concepts were matched with key ideas in the CLEP's eight modules (Table $2 \&$ Figure 2).

To confirm the validity of matching between 13 core concepts and developed CLEP's eight modules, a content validity index (CVI) was used with four experts who were both nursing management professors and nursing managers. The CVI was measured with a 4-point Likert scale (not valid at all to very valid) and was 1.0. Therefore, the 13 core concepts extracted from the systematic literature review were confirmed to be well reflected in the CLEP's modules.

The results of analyzing the period and operational methods of leadership programs showed that they were run over 2 3 days and lasted 9 18 hours. Based on these findings, the CLEP was formed using 8 modules that lasted 2 hours each, for a total of 16 hours over 2 days. It was designed using various performance-based learning tools: lectures, individual and team activities, group discussions, team presentations, and lecturer feedback. Jin and Kim [14] emphasized that leadership programs for university students should focus on engaging in various activities. Therefore, the CLEP leverages a variety of performancebased learning techniques to give nursing students the opportunity to understand the necessity and importance of leadership.

\section{Intervention}

The CLEP was implemented with the experimental group at a youth training center outside the school over 2 days. The CLEP's slogan was "Standing Firm through Communication and Cooperation." Day 1 covered modules 1 4, while Day 2 covered modules 5 8. Table 1 describes the details of the modules. In each module, $10 \mathrm{mi}-$ nutes were allocated for the introduction, 50 minutes for a team or individual activity, 30 minutes for group discussion, 20 minutes for team presentation, and 10 minutes for lecturer feedback.

The control group was recruited from the same nursing university. To prevent the dissemination of the experimental effects among control group participants, the experimental group completed the questionnaires at the camp site whereas the control group completed them at the school. After the study was completed, the researcher educated the control group about the CLEP and shared the results of the study with them.

\section{Data Collection}

Data were collected from October 6 to December 1, 2015. First, the participants were recruited through online and offline advertisements targeting second-year nursing students. Next, the participants were provided with explanations about the study purpose and context; those who understood and agreed to participate were asked to provide written consent. A pretest, CLEP intervention, and posttest were provided.

\section{Data Analysis}

The data were analyzed using SPSS 20.0 with the following methods: 1) The normality of the data was analyzed using the Shapiro-Wilk test; 2) Participants' general characteristics and leadership styles were examined using descriptive statistics; 3) The pre-homogeneity test was evaluated using the $x^{2}$ test, independent $\mathrm{t}$-test, and Wilcoxon rank-sum test; 4) The post difference test was scrutinized using a t-test and the Wilcoxon rank-sum test.

\section{Ethical Considerations}

The institutional review board of a nursing college (SWCN-201508-HR-002) approved this study. The researchers provided participants in both groups with written informed consent forms containing detailed information including about the purpose of the study and explained they had the right to withdraw at any time.

\section{RESULTS}

\section{General Characteristics}

The participants were all women. The mean age was $20.89 \pm 1.98$ years in the experimental group and $20.89 \pm 1.77$ in the control group $\left(x^{2}=0.00, p=1.000\right)$. Of the participants, $34(97.1 \%)$ were unmarried in the experimental group and $35(100.0 \%)$ were unmarried in the control group $\left(x^{2}=1.01, p=.314\right)$. Satisfaction with major was 2.46 \pm 0.85 in the experimental group and $2.37 \pm 0.84$ in the con- 
Table 2. Contents and Structure of the Leadership Enhancing Camp Program

\begin{tabular}{|c|c|c|c|c|}
\hline Module & Purpose & Learning theme & Main content & Methods \\
\hline $\begin{array}{l}\text { 1. Understanding } \\
\text { leadership }\end{array}$ & $\begin{array}{l}\text { 1. Understand concept of } \\
\text { leadership } \\
\text { 2. Understand definition } \\
\text { of a leader } \\
\text { 3. Understand leadership } \\
\text { in group activities }\end{array}$ & $\begin{array}{l}\text { 1. Concepts and needs of } \\
\text { Leadership } \\
\text { 2. Understanding } \\
\text { leadership theory } \\
\text { 3. Importance of role as a } \\
\text { leader }\end{array}$ & $\begin{array}{l}\text { 1. Leadership is a process of } \\
\text { organization by one person to } \\
\text { achieve common goals } \\
\text { 2. Students recognize leadership } \\
\text { involves goal orientation and } \\
\text { mutual affection }\end{array}$ & $\begin{array}{l}\text { Lecture, team } \\
\text { discussion, team } \\
\text { presentation, and } \\
\text { feedback }\end{array}$ \\
\hline 2. Introspection & $\begin{array}{l}\text { 1. Recognize importance } \\
\text { of self-understanding } \\
\text { 2. Understand myself } \\
\text { from human } \\
\text { relationships }\end{array}$ & $\begin{array}{l}\text { Increase } \\
\text { self-understanding and } \\
\text { self-esteem }\end{array}$ & $\begin{array}{l}\text { 1. Leadership helps individuals } \\
\text { overcome negative self-thought } \\
\text { since it is inclusively covering } \\
\text { personality, thoughts, behaviors, } \\
\text { habits, etc. } \\
\text { 2. Think positive in one's environment } \\
\text { 3. Give value to oneself }\end{array}$ & $\begin{array}{l}\text { Summarize module } \\
\text { cores, individual } \\
\text { activity, team } \\
\text { discussion, team } \\
\text { presentation, and } \\
\text { feedback }\end{array}$ \\
\hline 3. Visualization & $\begin{array}{l}\text { 1. Suggest directions for } \\
\text { establishing goals and } \\
\text { ways to practice } \\
\text { 2. Visualize your future }\end{array}$ & $\begin{array}{l}\text { Recognize importance of } \\
\text { vision and setting goals }\end{array}$ & $\begin{array}{l}\text { 1. Suggest directions for one's life and } \\
\text { future } \\
\text { 2. Promote importance of setting goals }\end{array}$ & $\begin{array}{l}\text { Lecture, team } \\
\text { discussion, team } \\
\text { presentation, and } \\
\text { feedback }\end{array}$ \\
\hline 4. Teamwork & $\begin{array}{l}\text { 1. Promoting a sense of } \\
\text { community through } \\
\text { team activities } \\
\text { 2. Recognize importance } \\
\text { of teamwork }\end{array}$ & $\begin{array}{l}\text { Leadership experience } \\
\text { through team activities }\end{array}$ & $\begin{array}{l}\text { 1. Recognize leadership is a key } \\
\text { qualification for living } \\
\text { harmoniously with others } \\
\text { 2. Recognize teamwork as essential for } \\
\text { establishing identity while in } \\
\text { university } \\
\text { 3. Recognize community activity as a } \\
\text { desirable leadership experience that } \\
\text { reflects real life } \\
\text { 4. Acknowledge and compliment } \\
\text { others }\end{array}$ & $\begin{array}{l}\text { Summarize module } \\
\text { cores, individual } \\
\text { activity, team } \\
\text { discussion, team } \\
\text { presentation, and } \\
\text { feedback }\end{array}$ \\
\hline 5. Empathizing & $\begin{array}{l}\text { 1. Recognize importance } \\
\text { of sympathizing and } \\
\text { listening } \\
\text { 2. Confirm effective } \\
\text { communication } \\
\text { methods } \\
\text { 3. Utilize prompt } \\
\text { communication skills }\end{array}$ & $\begin{array}{l}\text { Increasing } \\
\text { communication abilities } \\
\text { through sympathizing } \\
\text { and listening }\end{array}$ & $\begin{array}{l}\text { 1. Use listening and sympathizing to } \\
\text { understand key components of } \\
\text { leadership } \\
\text { 2. Recognize that understanding } \\
\text { others is critical }\end{array}$ & $\begin{array}{l}\text { Summarize module } \\
\text { cores, individual } \\
\text { activity, team } \\
\text { discussion, team } \\
\text { presentation, and } \\
\text { feedback }\end{array}$ \\
\hline 6. Negotiation & $\begin{array}{l}\text { 1. Understand conflict } \\
\text { coping types and learn } \\
\text { effective coping } \\
\text { strategies } \\
\text { 2. Understand ways to } \\
\text { express oneself that } \\
\text { leads to achieving goals }\end{array}$ & $\begin{array}{l}\text { Increase conflict coping } \\
\text { skills and negotiating } \\
\text { skills }\end{array}$ & $\begin{array}{l}\text { 1. Realize importance of negotiating to } \\
\text { achieve a goal } \\
\text { 2. Recognize conflict situations and } \\
\text { coping tips through teamwork }\end{array}$ & $\begin{array}{l}\text { Summarize module } \\
\text { cores, individual } \\
\text { activity, team } \\
\text { discussion, team } \\
\text { presentation, and } \\
\text { feedback }\end{array}$ \\
\hline $\begin{array}{l}\text { 7. Human } \\
\text { connection }\end{array}$ & $\begin{array}{l}\text { 1. Recognize that } \\
\text { relationships are } \\
\text { essential for successful } \\
\text { leadership } \\
\text { 2. Recognize need to } \\
\text { effectively overcome } \\
\text { stress }\end{array}$ & $\begin{array}{l}\text { Importance of human } \\
\text { relationships }\end{array}$ & $\begin{array}{l}\text { 1. Focus on past positive relationships } \\
\text { 2. Importance of health and stress } \\
\text { management to achieve goals }\end{array}$ & $\begin{array}{l}\text { Summarize module } \\
\text { cores, individual } \\
\text { activity, team } \\
\text { discussion, team } \\
\text { presentation, and } \\
\text { feedback }\end{array}$ \\
\hline $\begin{array}{l}\text { 8. Life } \\
\text { management }\end{array}$ & $\begin{array}{l}\text { 1. Recognize importance } \\
\text { of effective } \\
\text { time-management } \\
\text { 2. Recognize importance } \\
\text { of self-management }\end{array}$ & $\begin{array}{l}\text { Necessity of self- and } \\
\text { time-management }\end{array}$ & $\begin{array}{l}\text { 1. Understand personal } \\
\text { time-management skills and share } \\
\text { with team members }\end{array}$ & $\begin{array}{l}\text { Summarize module } \\
\text { cores, individual } \\
\text { activity, team } \\
\text { discussion, team } \\
\text { presentation, and } \\
\text { feedback }\end{array}$ \\
\hline
\end{tabular}


trol group $(\mathrm{t}=0.42, p=.860)$. There were no significant differences between the groups; therefore, the pre-homogeneity of the general characteristics was confirmed.

\section{Leadership Characteristics}

The different leadership types were: self-leadership 3.63 \pm 0.40 , transformational leadership $3.53 \pm 0.51$, and servant leadership $3.56 \pm 0.46$ in the experimental group, and $3.55 \pm 0.57$,
$3.53 \pm 0.55$, and $3.51 \pm 0.57$, respectively, in the control group. There were no significant differences between the groups; therefore, the pre-homogeneity of the leadership characteristics was determined (Table 3).

\section{Testing the Hypotheses}

Self $(\mathrm{t}=2.84, p=.006)$, transformational $(\mathrm{t}=3.13, p=.003)$, and servant $(\mathrm{t}=2.80, p=.007)$ leadership were significantly

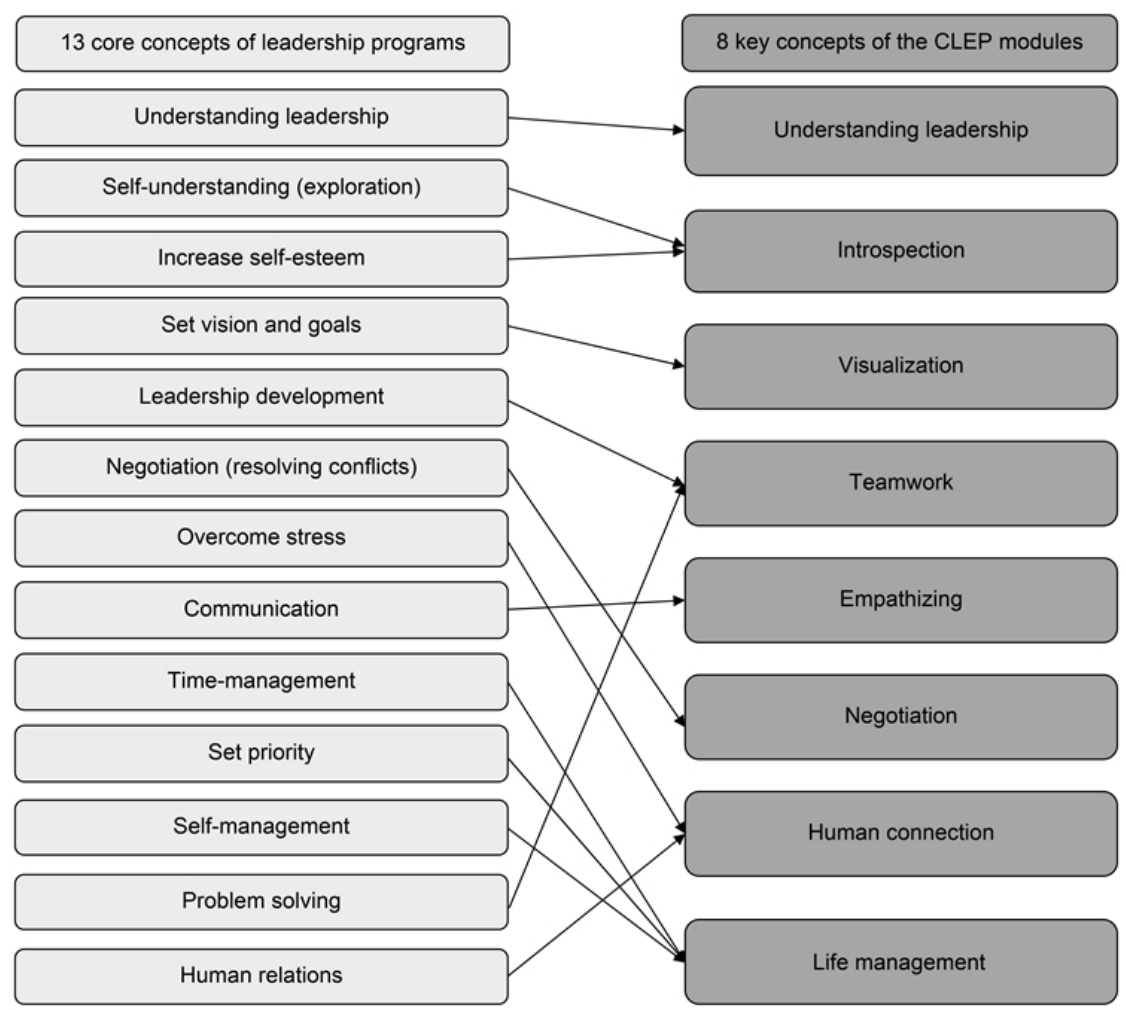

Figure 2. Mapping core concepts of leadership and key concepts of the camp-style leadership enhancement program (CLEP)

Table 3. Summary of Homogeneity and Hypothesis Test on Leadership Characteristics

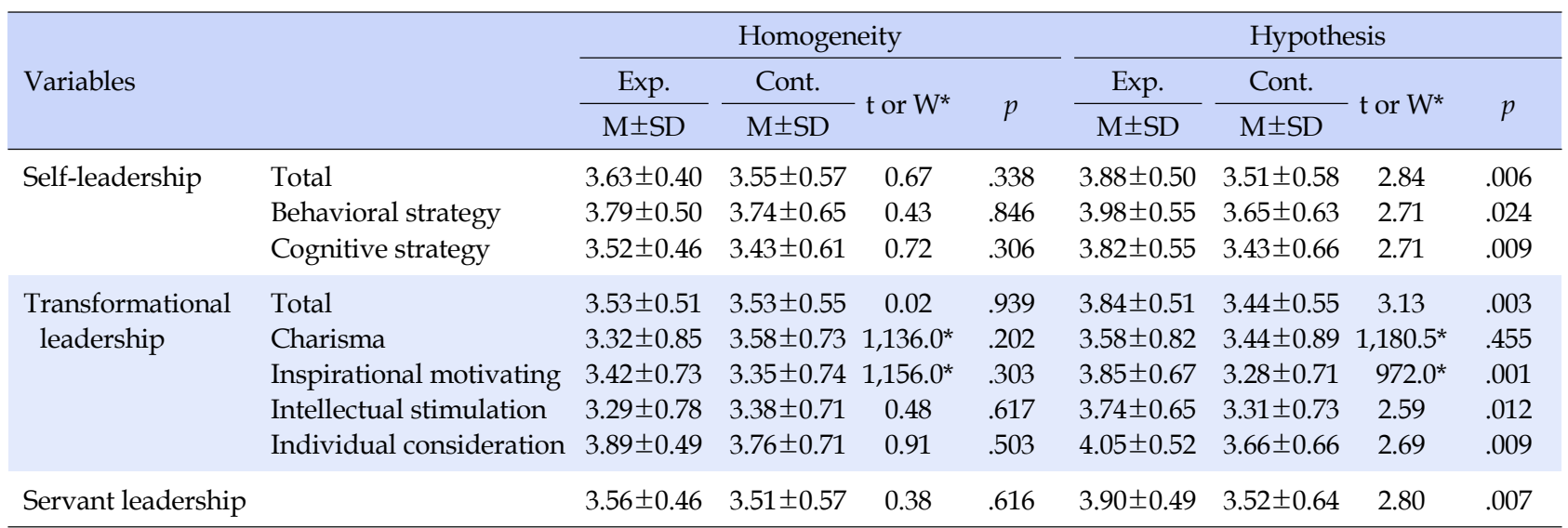

*Wilcoxon rank sum test. Exp.=Experiment group; Cont.=Control group. 
higher in the experimental group than in the control group. Therefore, hypotheses 1, 2, and 3 were statistically supported (Table 3 ).

\section{DISCUSSION}

It is critical for new nurses to enter the workplace with leadership abilities in today's complex healthcare environment, where systems focus on patient outcomes and safety. Nevertheless, new nurses are not sufficiently ready to be medical team leaders. Hence, it is important to enhance nursing students' leadership abilities [26]. They should fully learn and acquire leadership skills through training, with the goal of becoming future nursing managers. Advancing leadership skills during college is vital because college students are still developing self-esteem and independence.

As a result of the previous research, college students grow in the right direction by acquiring interpersonal skills as well as information about leadership, leadership attitudes, communication, decision making and stress management. However, it was difficult to find studies on leadership enhancement programs in the curriculum for nursing college students, and most of them were operated as liberal arts courses for general university students [27]. Therefore, in this study, the CLEP was developed in a none-curriculum type to reflect the educational characteristics of the nursing department. In the construction of the module of CLEP, various performance-based education methods including discussing, overcoming difficulties, learning through human relations, reflecting on experience, and presenting one's thoughts were included to enhance the effectiveness of the program.

After completing the CLEP, nursing students in the experimental group had significantly higher self, transformational, and servant leadership scores compared to the control group; thus, the hypotheses were supported. We found the CLEP significantly increased nursing students' leadership skills. In addition, based on these results, CLEP could be used as a performance-based, self-learning educational tool associated with nursing students.

Min et al. [11] showed that nursing college students' hopes and happiness improved after participating in a 2-day self-leadership training program. Furthermore, such programs will likely lead to a successful university life with positive self-management and internal motivation. Self-leadership reduced stress of nursing students undergoing clinical practice and led them to develop a positive coping style.

Transformational leadership is significantly correlated with job satisfaction. Park [28] emphasized the need for transformational leadership education and training by focusing on improving college students' self-development, human relationships, and job skills. Sung [12] presented a theoretical foundation of transformational leadership, which recognized the importance of team members' intrinsic motivation and maintaining cooperative relationships with them.

Servant leadership combines servants and leaders. This type of leadership differs from traditional leadership regarding the view of the leaders' new role. Gug [29] suggested that servant leadership positively affected the creativity and autonomy of organizational members and increased their sense of community and ownership.

Previous studies reported that camp-style leadership programs, when utilized outside of school, were effective among university students. Jin and Kim [14] created the "Techno-leadership Camp Program" as an activity that can be performed directly and experienced by engineering college students. Furthermore, short-term leadership camp programs can help improve college students' leadership skills. Janke et al.[30] reported that camp-style leadership programs at locations other than campus are effective so that students can feel "with" and have time for self-reflection. In this study, we used a systematic literature review as an evidence-based approach and designed the CLEP as a camp-style education program. Therefore, we expect that the CLEP can be utilized as an effective model for future leadership programs for nursing students.

The KABON [10] presented leadership as one of the 12 core competencies for graduating students. Given the sparse number of leadership development studies on nursing students, it is expected that the CLEP could be used as basic data for identifying nursing students' leadership competencies. Moreover, it provides practical guidance for leadership development in a performance-based nursing curriculum and allows for opportunities to encourage nursing students to design their futures.

The purpose of this study was to develop a leadership enhancement program that comprehensively reflects the factors commonly used in the composition of leadership programs. The three types of leadership were not included in the component of CELP because these were used as outcome measurement indicators. However, while conducting of the study, we identified the need to map the components of the three types of leadership to the modules of the CELP in order for more complete development. Therefore, we suggest that subsequent studies develop a more integrated leadership enhancement program that reflects the sub-components of self, transformational, and servant 
leadership in research design.

\section{CONCLUSION}

The CLEP was created for nursing students based on core concepts of leadership programs derived from a systematic literature review. The CLEP was comprised of a 2-day camp-style program consisting of lectures, team and individual activities, group discussions, team presentations, and feedback from the lecturer. The CLEP led to significant improvements in students' self, transformational, and servant leadership.

We conclude that the CLEP developed in this study constituted an effective educational medium for nurturing leadership that is critical for nursing students. As leadership education in nursing management courses is mostly based on theory-based lecture, we suggest that applying the CLEP to the student's portfolio as part of the none-curriculum will increase the effectiveness of leadership education in nursing management. Moreover, because such advancements in leadership skills raise job satisfaction and performance and positively influence empowerment for nurses working at clinical sites, this program could also be used as the basis to develop a leadership enhancement program for clinical nurses.

\section{REFERENCES}

1. Seo YS, Kim YC. A study on factors affecting the turnover intention and job involvement of nurses. Journal of the Korean Business Education Association. 2007;12:151-172.

2. Krugman M, Smith K, Goode CJ. A clinical advancement program: evaluating 10 years of progressive change. Journal of Nursing Administration. 2000;30(5):215-225.

3. Riley W. High reliability and implications for nursing leaders. Journal of Nursing Management. 2009;17(2):238-246. https://doi.org/10.1111/j.1365-2834.2009.00971.x

4. Kim EK, Kim SY, Jung MS, Jang KS, Kim J, Kim JK, et al. Current status and considerations for education in nursing management. Journal of Korean Academy of Nursing Administration. 2011;17(2):238-246.

https://doi.org/10.11111/jkana.2011.17.2.238

5. Kim HK, Ji HS, Ryu EK, Jeon MK. Comparison of job satisfaction, organizational commitment, and burnout by personalities of nurses in hospitals - Using Korean enneagram personality type indicators: KEPTI. Journal of Korean Clinical Nursing Research. 2005;11(1):109-121.

6. Park KN, Park MK. A study on nurses' self-leadership, organizational commitment and the nursing performance. Journal of Korean Academy of Nursing Administration. 2008;14(1):
63-71.

7. Institute of Medicine (US). Committee on the Work Environment for Nurses and Patient Safety. Keeping patients safe: Transforming the work environment of nurses. Washington, D.C.: National Academies Press; 2005.

8. Lee HS, Kim JK. Relationship among communication competence, communication types, and organizational commitment in hospital nurses. Journal of Korean Academy of Nursing Administration. 2010;16(4):488-496.

https://doi.org/10.11111/jkana.2010.16.4.488

9. Frellick M. The nurse practitioner will see you now. Advanced practice providers fill the physician gap. Hospitals \& Health Networks. 2011;85(7):44-46, 48-49.

10. Korean Accreditation Board of Nursing Education. Standard book for accreditation board of nursing education. Reference, vol 2012-12-03. Seoul: Korean Accreditation Board of Nursing Education; 2012.

11. Min S, Yu GW, Kim HS. The effect of self leadership training program on hope and happiness of nursing students. Proceedings of 2010 Fall Conference of the Korean Academic Association of Business Administration; 2010 November; Seoul. The Korean Academic Association of Business Administration; 2010. p. 381-397.

12. Sung EJ. The influence of transformational leadership on the degree of psychological well-being of undergraduates [master's thesis]. Seoul: Sookmyung Women's University; 2010.

13. Howatson-Jones IL. The servant leader. Nursing Management. 2004;11(3):20-24 https://doi.org/10.7748/nm2004.06.11.3.20.c1978

14. Jin SH, Kim TH. Development of customized technological leadership camp programs for engineering students. Journal of Engineering Education Research. 2010;13(6):111-121.

15. Choi Y. Leadership development program for college students: A case of self-transformational leadership model and its training program. Korean Journal of Human Resources Development. 2009;12(1):103-122.

16. Kang HC, Park MS, Cho KS, Cho BN, Yang SC, Kim KA, et al. Rediscovering of woman-leadership. Seoul: Sookmyung Women's University; 2005.

17. Jung TH. Effects of self leadership education on college students. The Journal of Korean Education. 2005;32(1):223-248.

18. Jung SE, Sook PY. Development and evaluation of a mentoring program designed to assist nursing students adjust to life in college and strengthen their leadership abilities. Journal of the Korea Academia-Industrial cooperation Society. 2015;16(7): 4595-4603. https://doi.org/10.5762/KAIS.2015.16.7.4595

19. Prussia GE, Anderson JS, Manz CC. Self-leadership and performance outcomes: The mediating influence of self-efficacy. Journal of Organizational Behavior. 1998;19(5):523-538. https://doi.org/10.2307/3100241 
20. Lee JS. The influence of university student's self-leadership on the employment strategies [master's thesis]. Seoul: Sookmyung Women's University; 2012.

21. Avolio BJ, Bass BM. Multifactor leadership questionnaire: Manual and sampler set. 3rd ed. Redwood City, CA: Mind Garden; 2004.

22. Greenleaf RK, Spears LC. Reflections on leadership: How Robert K. Greenleaf's theory of servant leadership influenced today's top management thinkers. New York: Wiley; 1995.

23. Jun HW. The effects of servant leadership on trust in supervisor, organizational trust and group cohesiveness in hotel employee. Tourism Research. 2012;36(2):187-212.

24. Moher D, Liberati A, Tetzlaff J, Altman DG. Preferred reporting items for systematic reviews and meta-analyses: The PRISMA statement. PLoS Medicine. 2009;6(7):e1000097. https://doi.org/10.1371/journal.pmed.1000097

25. Scottish Intercollegiate Guidelines Network. SIGN 50: A guideline developers' handbook. revised edition. Edinburgh: Scottish
Intercollegiate Guidelines Network; 2015.

26. Smith J, Crawford L. Medication errors and difficulty in first patient assignments of newly licensed nurses. JONA's Healthcare Law, Ethics, and Regulation. 2003;5(3):65-67.

27. Park MY. The needs analysis of the leadership education program for university students [master's thesis]. Seoul: Yonsei University; 2009.

28. Park HH. The effect of leadership development for university students. The Korean Journal of Human Development. 2011;18 (2):1-20.

29. Gug SO. The effect of transformational leadership and servant leadership of school principal on teachers' efficacy and organizational commitment [dissertation]. Gongju: Kongju National University; 2009.

30. Janke KK, Traynor AP, Sorensen TD. Student leadership retreat focusing on a commitment to excellence. American Journal of Pharmaceutical Education. 2009;73(3):48.

https://doi.org/10.5688/aj730348 